University of Nebraska - Lincoln

DigitalCommons@University of Nebraska - Lincoln

$9-2008$

\title{
Interlibrary Loan Patron Satisfaction at the Wichita State University Libraries
}

Ted Naylor

University of Nebraska - Lincoln, tnaylor@unlnotes.unl.edu

Judith A. Wolfe

University of Nebraska-Lincoln, jwolfe4@unl.edu

Follow this and additional works at: https://digitalcommons.unl.edu/libraryscience

Part of the Library and Information Science Commons

Naylor, Ted and Wolfe, Judith A., "Interlibrary Loan Patron Satisfaction at the Wichita State University Libraries" (2008). Faculty Publications, UNL Libraries. 175.

https://digitalcommons.unl.edu/libraryscience/175

This Article is brought to you for free and open access by the Libraries at University of Nebraska-Lincoln at DigitalCommons@University of Nebraska - Lincoln. It has been accepted for inclusion in Faculty Publications, UNL Libraries by an authorized administrator of DigitalCommons@University of Nebraska - Lincoln. 


\title{
Interlibrary Loan Patron Satisfaction at the Wichita State University Libraries
}

\author{
Ted E. Naylor \\ Judith A. Wolfe
}

\begin{abstract}
In 2004, the Wichita State University (WSU) interlibrary loan services completed a study of currently available interlibrary loan software. Based upon the results of the study, the library chose the Interlibrary Loan Internet Accessible database (ILLiad). After implementation, individual training was offered to patrons. In 2006, staff decided to survey patrons' satisfaction. The general purpose of the survey was to determine whether users had accepted the new system, to measure satisfaction with turnaround time, delivery method and the print quality and usefulness of the received material. This article contains a brief description of interlibrary loan operations at WSU, a review of interlibrary loan satisfaction literature and a discussion of the design, implementation, results and analysis of the survey.
\end{abstract}

KEYWORDS. Interlibrary loan, ILLiad, user surveys, satisfaction surveys

Ted E. Naylor is Special Projects Librarian (E-mail: tnaylor@unlnotes.unl.edu); Judith A. Wolfe is Catalog and Metadata Librarian and Assistant Professor (E-mail: jwolf1@unlnotes.unl.edu); both are at University of Nebraska-Lincoln, 322 Love Library Lincoln, NE 68588-4100.

The authors would like to thank Mary Bolin, Chair, Technical Services, University of Nebraska-Lincoln and Beth McNeil, Associate Dean, University of Nebraska-Lincoln for their review of this manuscript.

Journal of Interlibrary Loan, Document Delivery \& Electronic Reserve Vol. 18(3) 2008

Available online at http://jildd.haworthpress.com

(C) 2008 by The Haworth Press. All rights reserved. doi:10.1080/10723030802186371 


\section{INTRODUCTION}

In 2004, the Wichita State University (WSU) interlibrary loan services completed a study of currently available interlibrary loan software. The study was initiated to prepare for the OCLC interlibrary loan module upgrade and to determine if there was a better and quicker way to put interlibrary loan material into the hands (or computers) of WSU's patrons.

In late 2004, based upon the results of the study, the library chose the Interlibrary Loan Internet Accessible database (ILLiad). Staff implemented ILLiad lending in early 2005 and the borrowing unit began using ILLiad in mid-2005. No specific publicity campaign was undertaken. After implementation, individual training was offered to patrons as needed. The current WSU ILLiad web interface is self-explanatory and the "frequently asked questions" page is linked to the basic WSU interlibrary loan homepage.

In 2006, staff decided to survey patron satisfaction, in order to determine how well the new service was accepted by WSU users. Day-today interaction with patrons indicated that the overall response was very positive, but staff wished to define and address any questions or perceived problems, and to determine overall patron satisfaction (or dissatisfaction) with the ILLiad service.

After implementation of the WSU ILLiad system, it was important to evaluate the software from a user's perspective. The general purpose of the survey was to determine whether the user had adjusted to the new system, and to measure satisfaction with turnaround time, delivery method and the print quality and usefulness of material received. We also hoped to identify any problems that might be applicable to interlibrary loan services in general.

This article contains a brief description of interlibrary loan operations at WSU, a review of interlibrary loan satisfaction literature and a discussion of the design, implementation, analysis and results of the WSU survey.

\section{INTERLIBRARY LOAN AT WSU}

WSU is located in south central Kansas in the state's largest metropoli$\tan$ area. The university serves approximately 14,000 students through more than 60 undergraduate degree programs in more than 200 areas of study. WSU has 515 full-time faculty members and offers 56 master's degrees, additional specialist and certificate programs, and 9 doctoral 
programs. The WSU University Libraries contain more than one million volumes and employ 16 professional librarians and 34 support staff.

The current interlibrary loan services staff consists of two full-time staff members, who report to the head of access services, and approximately 20 hours per week of student assistance. The majority of borrowing and lending requests are handled via the OCLC system and nearly $70 \%$ of borrowed and non-returnable material is acquired within the state of Kansas. WSU interlibrary loan processes approximately 12,000 borrowing and 20,000 lending requests per calendar year. WSU interlibrary loan used the SaveIt and Clio software before migration to ILLiad.

\section{LITERATURE REVIEW}

Before beginning the survey, the authors reviewed 34 articles, of which 16 directly related to the topic of interlibrary loan user satisfaction. The other articles had broader, library-wide implications concerning overall patron satisfaction with network delivery and library systems in general.

Of the previous 16 interlibrary loan user surveys, turnaround time and cost appear to have been the main subjects of study. Since WSU subsidizes the cost of interlibrary loan to all WSU faculty and students, cost was not factored into the WSU survey. Perrault and Arseneau's (1992) study at Louisiana State University concerned identification of the "Perceived print quality of interlibrary loan service among the users" (Perrault \& Arseneau, 1995). Their findings indicated a higher satisfaction level among the faculty respondents as opposed to the graduate student respondents. The study also found both graduate and faculty users were more interested in ultimately receiving material than they were in the turnaround time or cost.

Fong reported on the value of "obtaining the materials" (Fong, 1996) as the most important aspect of interlibrary loan, which outweighed speed and cost. Fong also divided the participants' comments into ten categories: "speed/timeliness, value, staff interactions, request process, delivery, reliability/print print quality and communications with interlibrary loan office, access versus acquisitions, cost and satisfaction" (Fong).

The WSU survey comments were organized by positive, negative, or "other" with a further breakdown by patron-added comments. Of the surveys reviewed, only three others measured and discussed the print quality of received material. 
Like the WSU survey, many other surveys used populations that included a single institution or small region. The WSU survey was available online and could be accessed by any web user, but was not advertised or distributed past the boundaries of the University population, especially after E-mail contact with ILLiad registered users. While the scope of the WSU survey was limited to one institution, the potential respondent pool was larger than many of the other surveys. The interlibrary loan/ILLiad study by Tonn (2003), for example, dealt with a total population of 130 students, faculty and staff. The WSU survey population included over 2,700 potential WSU ILLiad-registered, students, faculty and staff.

\section{METHODOLOGY}

In September of 2006, the authors established access to the WSU Libraries Survey, Interlibrary Loan Use and Satisfaction (Appendix A). The survey was made available via the World Wide Web through a link on the WSU Interlibrary Loan ILLiad welcome page.

Prior to mounting the survey on the web site, the authors received Institutional Review Board (IRB) approval to conduct the survey. This was a two-step process because the data gathered would be shared by the author at WSU and the coauthor at the University of Nebraska-Lincoln (UNL). Both Universities' IRB offices had to grant approval. This process took several months, but approval was obtained in 2006.

The survey tool was created using FrontPage software and data was collected through the FrontPage utility. The survey was intentionally designed to be brief and took only a few minutes to complete in hopes of increasing patron participation. This was in contrast to many of the surveys examined during the literature review process. Some of the other survey questions were similar to those included in the WSU survey. The WSU survey questions that differed from other surveys solicited information about satisfaction with pdf delivery, print quality of the material received, and usefulness of the material to the patron's research. Of the articles reviewed, only four included the survey as an appendix.

During the first few weeks after the survey availability, few responses were received. At this point, a general E-mail was sent to all registered ILLiad users. The E-mail invited patrons to provide feedback by completing the survey. This significantly increased patron response. The survey was closed to participants on October 15, 2006, after approximately six weeks of accessibility. 
The WSU survey included ten questions, two demographic questions followed by eight questions about ILLiad, document delivery, timeliness and print quality. Five of the eight questions provided comment areas for respondents to include further specific feedback (Appendix B). Based on the ILLiad database, there was a potential population of over 2,700 respondents. At the time of the survey, ILLiad registered users consisted of 359 faculty members, 1,328 graduate students, 744 undergraduate students and 99 university staff. An additional 171 users were Wichita community users, WSU distance education students or were not identified in ILLiad.

Of the 2,700 registered ILLiad users, 250 participants submitted a survey, a response rate of $9.26 \%$. The faculty and graduate students make up 63\% $(1,687)$ of the total registered users. Of the faculty and graduate student ILLiad-registered user population (44\%), 233 responded to the survey. Eighty-nine (38\%) respondents were faculty, 144 (62\%) were graduate students, 11 were undergraduate students and six were staff members. Respondents were from eight general academic disciplines representing 56 departments or colleges. Because of the low number of undergraduates $(1.48 \%)$ and staff $(6.06 \%)$, the authors decided, those responses would not be included.

Of the 89 faculty respondents, the discipline with the most participants was Social Sciences with $20(23 \%)$. Both the Humanities and the Science disciplines each had 15 (17\%) responses. Eleven (12\%) Business faculty members responded as well as nine (10\%) Education and nine (10\%) Health Sciences faculty. Fine Arts was represented by six (7\%) faculty and Engineering by two (2\%) respondents.

The Engineering graduate students, historically heavy users of ILL, reflected the highest survey response with $50(35 \%)$ participants. The other graduate respondents were 27 (19\%) Social Sciences students, $20(14 \%)$ Humanities, 18 (13\%) Education, 11 (7\%) Health Sciences, $6(4 \%)$ Fine Arts, and $6(4 \%)$ Science disciplines. The remaining four (3\%) graduate participants were from the School of Business. Both the faculty and graduate student respondents included two participants who did not report a specific discipline.

\section{ANALYSIS AND RESULTS}

The authors used SPSS to analyze the data. The questions analyzed in this section of the article are from the Document Delivery section of the 
survey and include the questions 3 through 8 (Appendix A). Comments on interlibrary loan are reviewed and discussed later in this article.

Question 3. WSU has implemented an interlibrary loan patron interface, named ILLiad, for faculty, staff and students. Have you used ILLiad?

When asked if they were familiar with the new ILLiad system, 94\% (219) of the participants responded yes (Table 1). Only 6\% (14) responded either "no" or "not familiar." Ninety-two percent of the faculty and $95 \%$ of the graduate students are familiar with ILLiad.

Familiarity with ILLiad was examined by discipline. There are eight general discipline categories: business, education, engineering, fine arts, health sciences, humanities, sciences, social sciences and unknown. Overall, familiarity with ILLiad by discipline was led by the engineering department with 52 participants responding yes. The Social sciences (43) and the humanities (31) follow closely behind (Table 2).

The overall response to this question indicates that respondents were familiar with the new ILLiad system.

Question 4. How often do you submit interlibrary loan requests for material not held by WSU Libraries?

For the purposes of the survey, a "Few times per semester" is meant to be 1 to 10 uses, "Several times a month" is meant to be 5 to 15 uses,

TABLE 1. Familiarity with ILLiad by Status

\begin{tabular}{lcccc}
\hline Status & Yes & No & Not Familiar & Total \\
\hline Faculty & 82 & 1 & 6 & 89 \\
Graduate student & 137 & 3 & 4 & 144 \\
Total & 219 & 4 & 10 & 233 \\
\hline
\end{tabular}
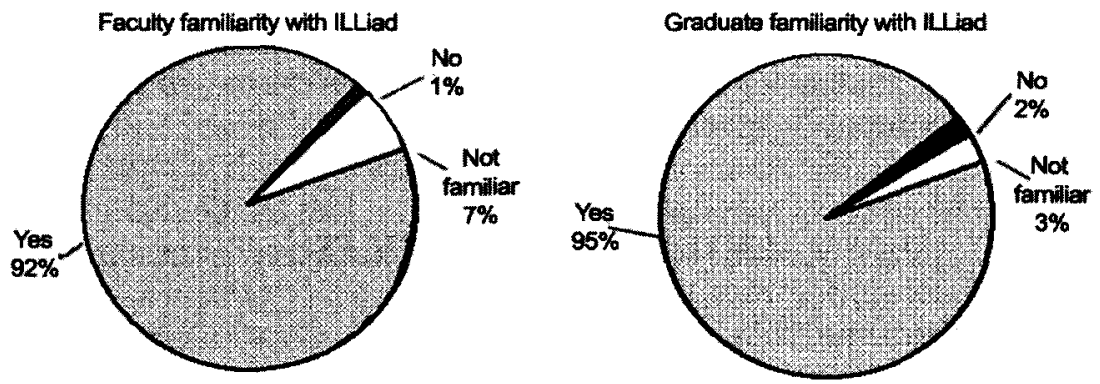
TABLE 2. Familiarity with ILLiad by Discipline

\begin{tabular}{lrrrrrrr}
\hline & Yes & Yes & No & No & $\begin{array}{c}\text { Not } \\
\text { Familiar }\end{array}$ & $\begin{array}{c}\text { Not } \\
\text { Familiar }\end{array}$ & Total \\
\hline Business & 13 & $87 \%$ & 1 & $7 \%$ & 1 & $7 \%$ & 15 \\
Education & 25 & $93 \%$ & 0 & $0 \%$ & 2 & $7 \%$ & 27 \\
Engineering & 52 & $100 \%$ & 0 & $0 \%$ & 0 & $0 \%$ & 52 \\
Fine arts & 11 & $92 \%$ & 0 & $0 \%$ & 1 & $8 \%$ & 12 \\
Health sciences & 20 & $100 \%$ & 0 & $0 \%$ & 0 & $0 \%$ & 20 \\
Humanities & 31 & $89 \%$ & 3 & $9 \%$ & 1 & $3 \%$ & 35 \\
Sciences & 21 & $100 \%$ & 0 & $0 \%$ & 0 & $0 \%$ & 21 \\
Social sciences & 43 & $91 \%$ & 0 & $0 \%$ & 4 & $9 \%$ & 47 \\
Unknown & 3 & $75 \%$ & 0 & $0 \%$ & 1 & $25 \%$ & 4 \\
Total & 219 & $94 \%$ & 4 & $2 \%$ & 10 & $4 \%$ & 233 \\
\hline
\end{tabular}

and "Several times a week" is meant to be 5 or more uses per week-although the authors did not actually use numbers in the survey form.

When participants were asked how frequently they use the interlibrary loan system, $133(57 \%)$ indicated that their pattern of use was a few times during the semester. Faculty and graduate students' use was similar throughout the four different categories. Fifty-seven percent of faculty use interlibrary loan services a few times during a semester, while graduate students' use pattern for this category was $58 \%$, which correlated to the overall use pattern of $57 \%$ (Table 3 ).

A "few times during a semester" and "several times a month" were the two responses selected repeatedly to indicate how frequently the participant used interlibrary loan. The analysis by discipline demonstrated that those in social sciences (32) and engineering (25) were the heaviest users of interlibrary loan services during the semester. This was followed closely by education (20) and humanities (16). The most common response about interlibrary loan use, for both faculty and graduate students, was a "few times during the semester" (Table 4).

Question 5. ILLiad uses desktop delivery of articles in PDF format via Web page. Are you satisfied with this service?

When participants were asked about satisfaction with the PDF format, an overwhelming majority indicated they were satisfied with PDFs. Two hundred and five (88\%) participants were satisfied with the delivery of articles via the Web. Larger portions of graduates were satisfied (93\%) than faculty $(81 \%)$ (Tables 5 and 6). 
TABLE 3. Frequency of Interlibrary Loan Use by Status

\begin{tabular}{lccccr}
\hline & $\begin{array}{c}\text { Few Times During } \\
\text { a Semester } \\
\text { 1-10 Times }\end{array}$ & $\begin{array}{c}\text { Several Times } \\
\text { a Month } \\
\text { 5-15 Times }\end{array}$ & $\begin{array}{c}\text { Several Times } \\
\text { a Week } \\
\text { 5 or More }\end{array}$ & Never & Total \\
\hline $\begin{array}{l}\text { Faculty } \\
\begin{array}{l}\text { Graduate } \\
\text { student }\end{array}\end{array}$ & 50 & 35 & 4 & 0 & 89 \\
$\begin{array}{l}\text { Total } \\
\text { The }\end{array}$ & 83 & 50 & 9 & 2 & 144 \\
\hline
\end{tabular}
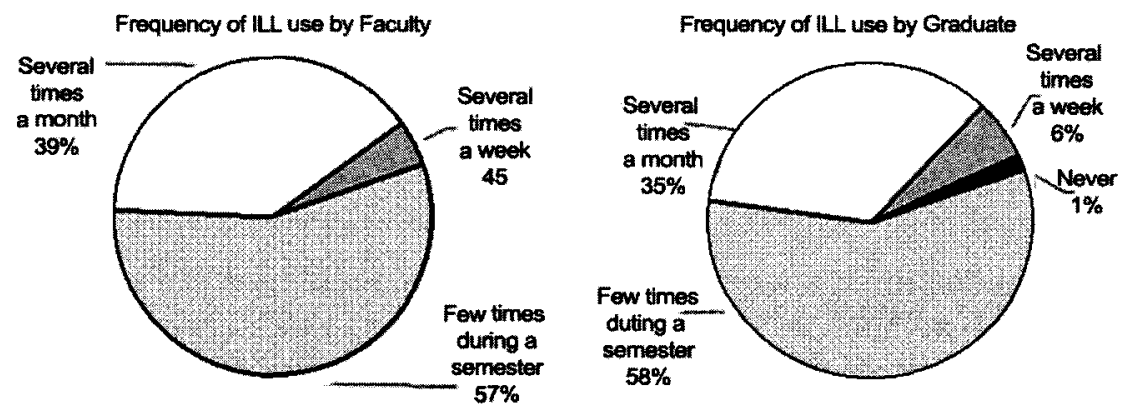

Engineering leads the way in satisfaction with $90 \%$ (47) of 52 respondents answering yes. Humanities $83 \%$ (29) and social sciences $81 \%$ (38) following close behind. The overall acceptance of the use of pdf as a delivery format was proven for the WSU ILLiad users who responded to the survey.

Question 6. If you have received articles from ILLiad, how do you rate the overall print quality of the items received?

Table 7 provides information about respondents' satisfaction with the overall print quality of the document delivered. One-half of the faculty and $52 \%$ of the graduate students considered the print quality excellent. Less than one-third of the respondents selected "good" for print quality. There were only 10 respondents, who thought the print quality was poor. Twenty-two participants did not respond to this question. Despite the fact that half the respondents considered the print quality to be excellent the comments generated a somewhat different picture.

There were 17 negative comments about print quality of the document. Of the 17 comments, four respondents had also selected "excellent" for question 6. "Good" was selected by 10 participants who also 


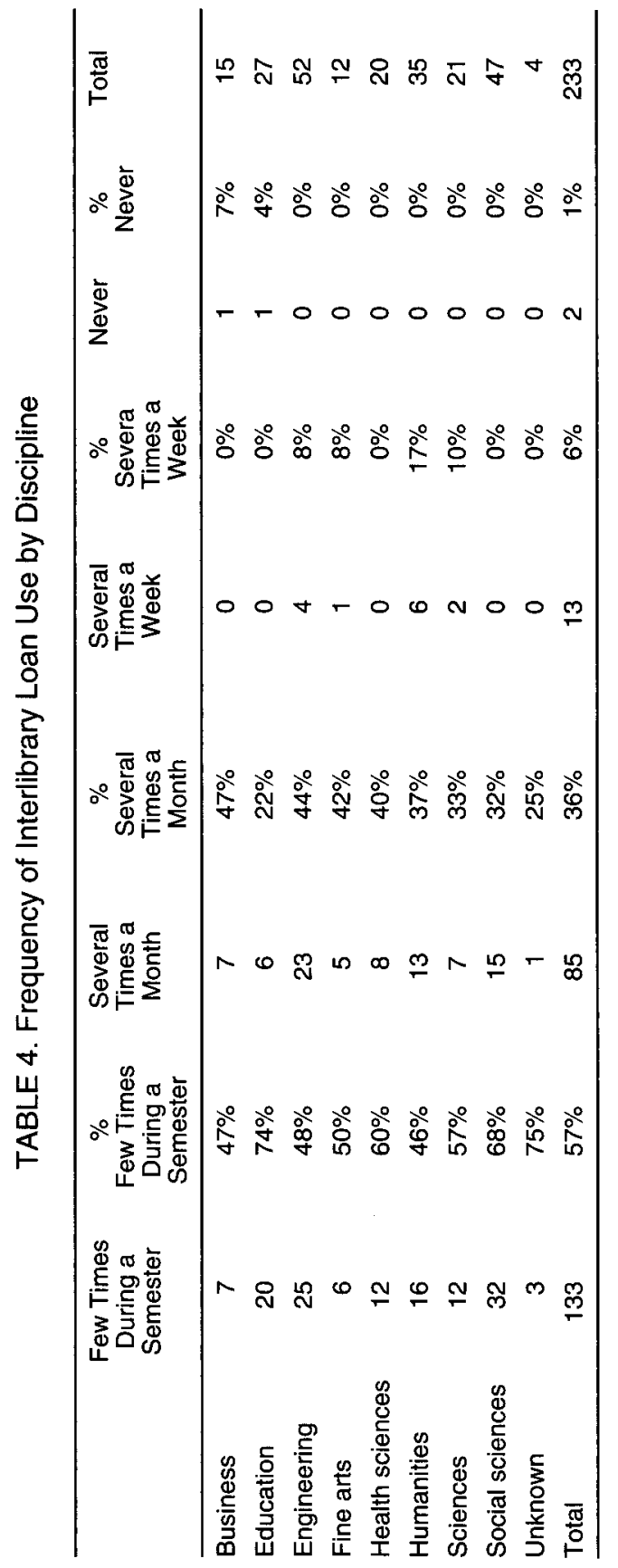


TABLE 5. Satisfaction with PDF by Status

\begin{tabular}{lrcccc}
\hline & Yes & No & Not Familiar & N/R & Total \\
\hline Faculty & 72 & 4 & 8 & 5 & 89 \\
Graduate student & 133 & 3 & 6 & 2 & 144 \\
Total & 205 & 7 & 14 & 7 & 233 \\
\hline
\end{tabular}
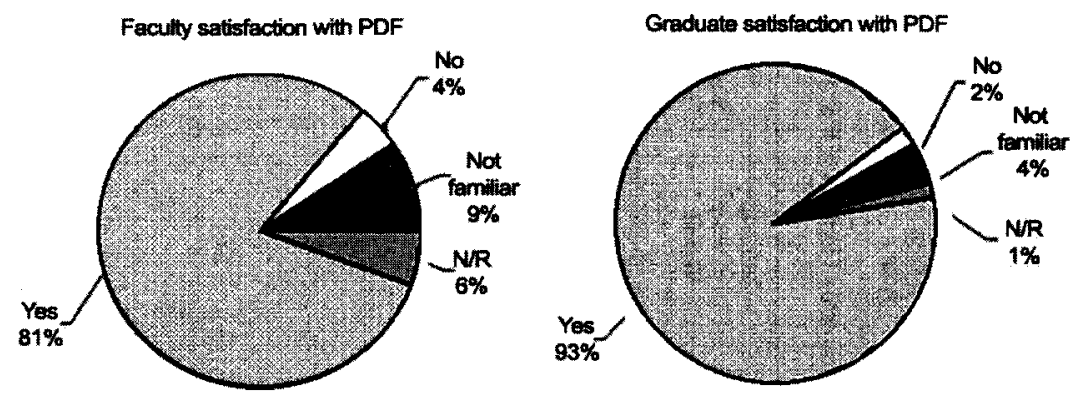

TABLE 6. Satisfaction with PDF by Discipline

\begin{tabular}{|c|c|c|c|c|c|c|c|c|c|}
\hline & Yes & Yes & No & No & $\begin{array}{c}\text { Not } \\
\text { Familiar }\end{array}$ & $\begin{array}{c}\text { Not } \\
\text { Familiar }\end{array}$ & $N / R$ & $N / R$ & Total \\
\hline Business & 13 & $87 \%$ & 1 & $7 \%$ & 0 & $0 \%$ & 1 & $7 \%$ & 15 \\
\hline Education & 25 & $93 \%$ & 0 & $0 \%$ & 2 & $7 \%$ & 0 & $0 \%$ & 27 \\
\hline Engineering & 47 & $90 \%$ & 2 & $4 \%$ & 3 & $6 \%$ & 0 & $0 \%$ & 52 \\
\hline Fine arts & 9 & $75 \%$ & 0 & $0 \%$ & 1 & $8 \%$ & 2 & $17 \%$ & 12 \\
\hline Health sciences & 20 & $100 \%$ & 0 & $0 \%$ & 0 & $0 \%$ & 0 & $0 \%$ & 20 \\
\hline Humanities & 29 & $83 \%$ & 3 & $9 \%$ & 1 & $3 \%$ & 2 & $6 \%$ & 35 \\
\hline Sciences & 21 & $100 \%$ & 0 & $0 \%$ & 0 & $0 \%$ & 0 & $0 \%$ & 21 \\
\hline Social sciences & 38 & $81 \%$ & 1 & $2 \%$ & 6 & $13 \%$ & 2 & $4 \%$ & 47 \\
\hline Unknown & 3 & $75 \%$ & 0 & $0 \%$ & 1 & $25 \%$ & 0 & $0 \%$ & 4 \\
\hline Total & 205 & $88 \%$ & 7 & $3 \%$ & 14 & $6 \%$ & 7 & $3 \%$ & 233 \\
\hline
\end{tabular}

had negative comments. The comments from these 14 participants seemed in conflict with their response to this question (Table 8).

Social Sciences rated the print quality of documents delivered to be excellent (26) or good (13) and engineering chose excellent (25), 48\% of those responding. 
TABLE 7. Satisfaction with Overall Print Quality by Status

\begin{tabular}{lcccccc}
\hline & Excellent & Good & Acceptable & Poor & N/R & Total \\
\hline Faculty & 45 & 26 & 5 & 0 & 13 & 89 \\
Graduate student & 73 & 55 & 5 & 2 & 9 & 144 \\
Total & 118 & 81 & 10 & 2 & 22 & 233 \\
\hline
\end{tabular}
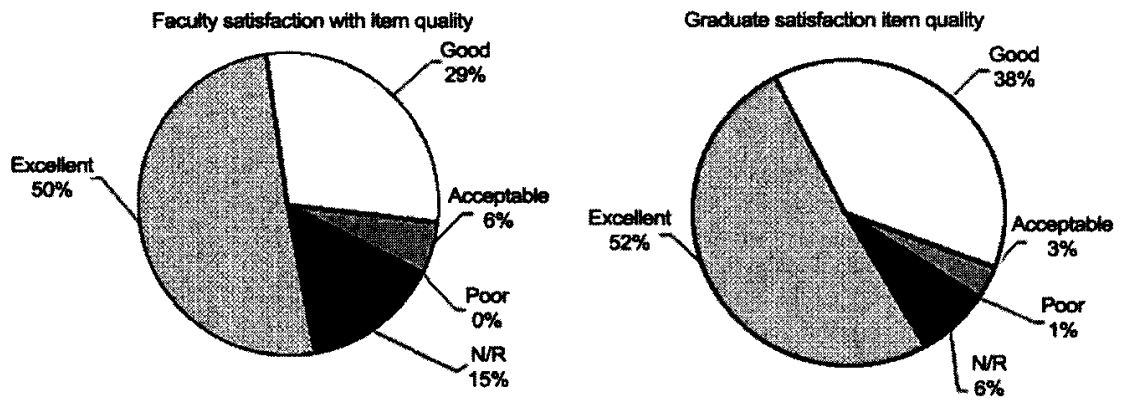

Question 7. Was the material you received useful in your research?

When participants were asked if the material received was useful to their research, 71\% (165) reported it to be very useful. Faculty and graduate students both selected "very useful" more than $70 \%$ of the time (Table 9).

When this question was broken down by discipline, $81 \%$ of the respondents from education reported that the material was very useful. Engineering (37) and social sciences (32) followed closely behind with $68 \%$ of the participants reporting that the material was very useful (Table 10).

Overall, respondents reported that the material was useful to their research.

Question 8. Are you satisfied with the turnaround time from the date that you submitted your requests to the time that you received your material?

One hundred and forty-five of the participants were very satisfied with the turnaround time. This is $67 \%$ of all participants. Thirty-three percent of the respondents were satisfied with the turnaround time. Graduate students were less satisfied than faculty, with only $54 \%$ selecting "very satisfied" as their response, compared to faculty who selected this option $75 \%$ of the time (Table 11 ). 


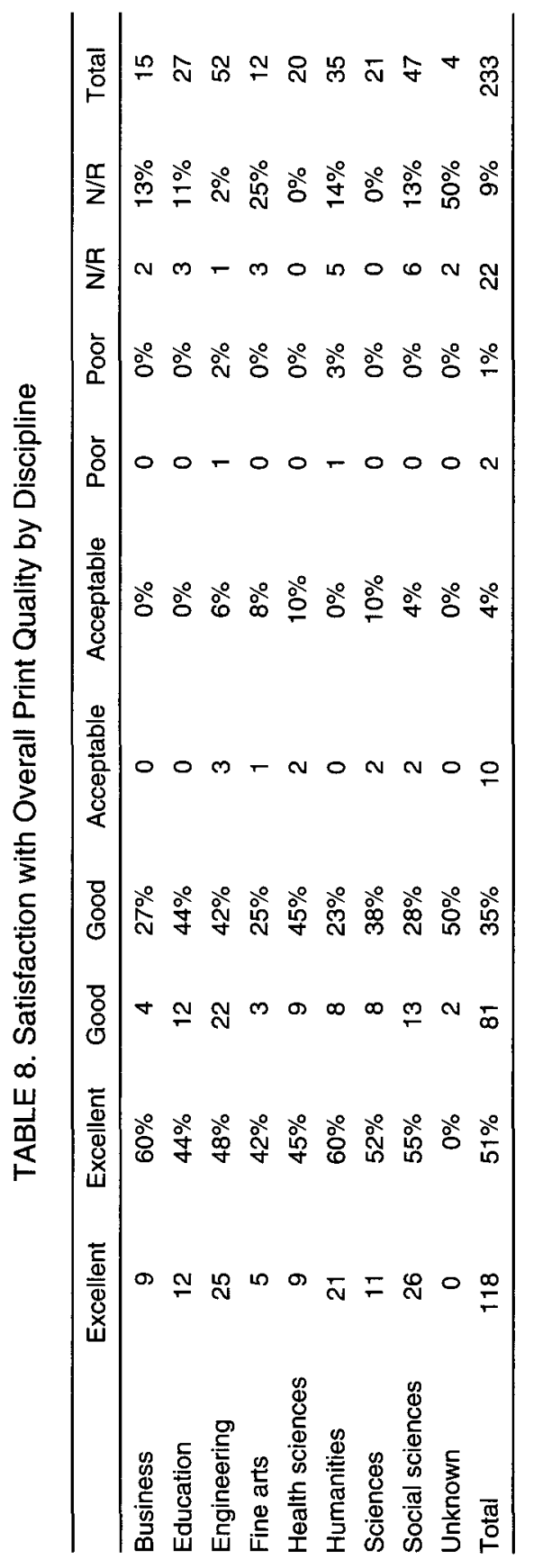


TABLE 9. Usefulness of Material by Status

\begin{tabular}{lccccc}
\hline & Very Useful & Useful & Not Useful & N/R & Total \\
\hline Faculty & 64 & 15 & 1 & 9 & 89 \\
Graduate student & 101 & 36 & 0 & 7 & 144 \\
Total & 165 & 51 & 1 & 16 & 233 \\
\hline
\end{tabular}
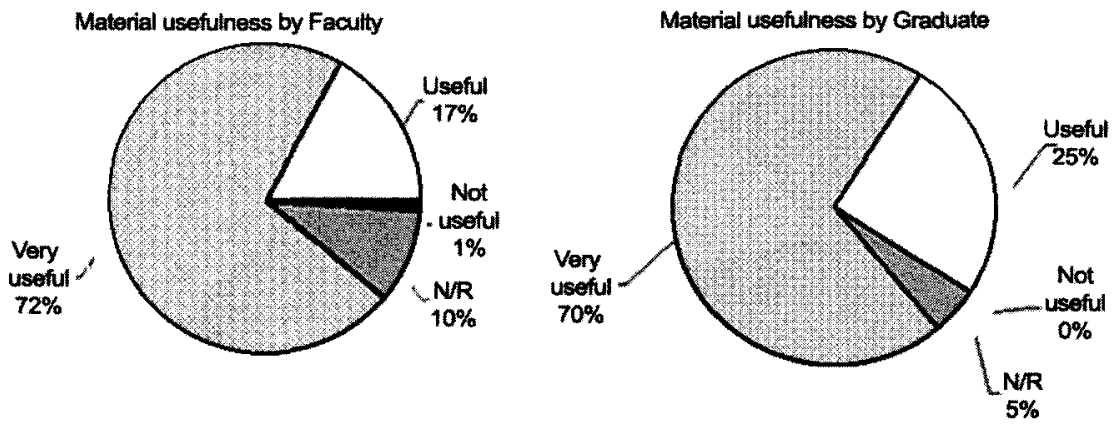

TABLE 10. Usefulness of Material by Discipline

\begin{tabular}{lrcrrrrrrr}
\hline & $\begin{array}{c}\text { Very } \\
\text { Useful }\end{array}$ & $\begin{array}{c}\text { Very } \\
\text { Useful }\end{array}$ & Useful & Useful & $\begin{array}{c}\text { Not } \\
\text { Useful }\end{array}$ & $\begin{array}{c}\text { Not } \\
\text { Useful }\end{array}$ & N/R & N/R & Total \\
\hline Business & 11 & $73 \%$ & 3 & $20 \%$ & 0 & $0 \%$ & 1 & $7 \%$ & 15 \\
Education & 22 & $81 \%$ & 3 & $11 \%$ & 0 & $0 \%$ & 2 & $7 \%$ & 27 \\
Engineering & 37 & $71 \%$ & 15 & $29 \%$ & 0 & $0 \%$ & 0 & $0 \%$ & 52 \\
Fine arts & 7 & $58 \%$ & 4 & $33 \%$ & 0 & $0 \%$ & 1 & $8 \%$ & 12 \\
Health sciences & 17 & $85 \%$ & 3 & $15 \%$ & 0 & $0 \%$ & 0 & $0 \%$ & 20 \\
Humanities & 24 & $69 \%$ & 4 & $11 \%$ & 1 & $3 \%$ & 6 & $17 \%$ & 35 \\
Sciences & 15 & $71 \%$ & 6 & $29 \%$ & 0 & $0 \%$ & 0 & $0 \%$ & 21 \\
Social sciences & 32 & $68 \%$ & 11 & $23 \%$ & 0 & $0 \%$ & 4 & $9 \%$ & 47 \\
Unknown & 0 & $0 \%$ & 2 & $50 \%$ & 0 & $0 \%$ & 2 & $50 \%$ & 4 \\
Total & 165 & $71 \%$ & 51 & $22 \%$ & 1 & $0 \%$ & 16 & $7 \%$ & 233 \\
\hline
\end{tabular}

Engineers were the most satisfied, with $94 \%$ of respondents selecting "very satisfied" or "satisfied." Social sciences followed closely behind, with $89 \%$ reporting at the very satisfied or satisfied level. Overall, the majority of the participants reported being satisfied with the turnaround time (Table 12). 
TABLE 11. Turnaround Time Satisfaction by Status

\begin{tabular}{lccccc}
\hline & Very Satisfied & Satisfied & Not Satisfied & N/R & Total \\
\hline Faculty & 67 & 15 & 2 & 5 & 89 \\
Graduate student & 78 & 56 & 6 & 4 & 144 \\
Total & 145 & 71 & 8 & 9 & 233 \\
\hline
\end{tabular}
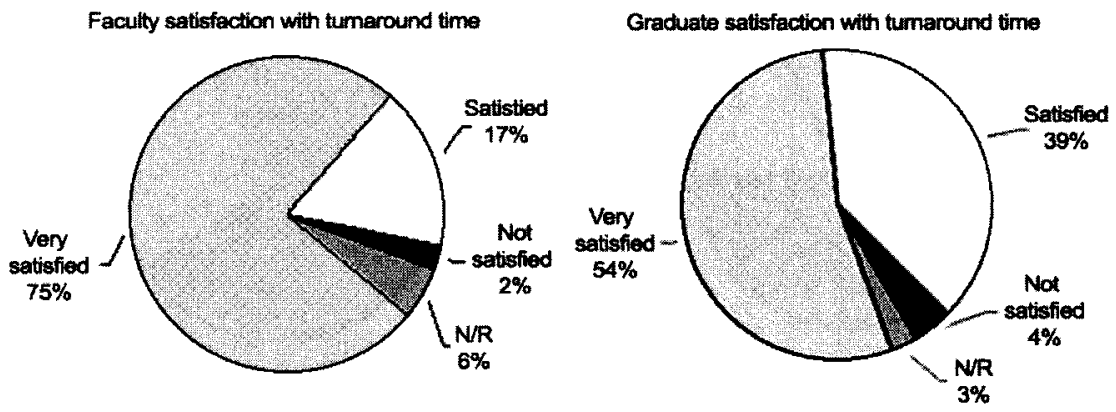

\section{CONCLUSION}

As expected, the users of the WSU interlibrary loan service are for the most part, satisfied with the service, and have approved the ILLiad system. Patrons of all statuses are happy with the delivery time, print quality and usefulness of the material provided by interlibrary loan. Negative responses constitute a small percentage of the total responses. The greatest dissatisfaction was with turnaround time, but only $5 \%$ of the total responses, against the more than $92 \%$ of "very satisfied" and "satisfied" respondents.

The main problems users encountered are related to the print quality of the pdf documents. Many of those complaints are similar to those encountered with paper documents: photographs or tables are unclear and the overall print quality is poor. There were some complaints with electronically delivered material because some pages were "upside down" within the pdf.

One of the more interesting aspects of this survey is the comments that highlight the different perspectives of the WSU interlibrary loan users. Again, the overall response is extremely positive and most patrons are pleased with the electronically delivered material. The comments are 


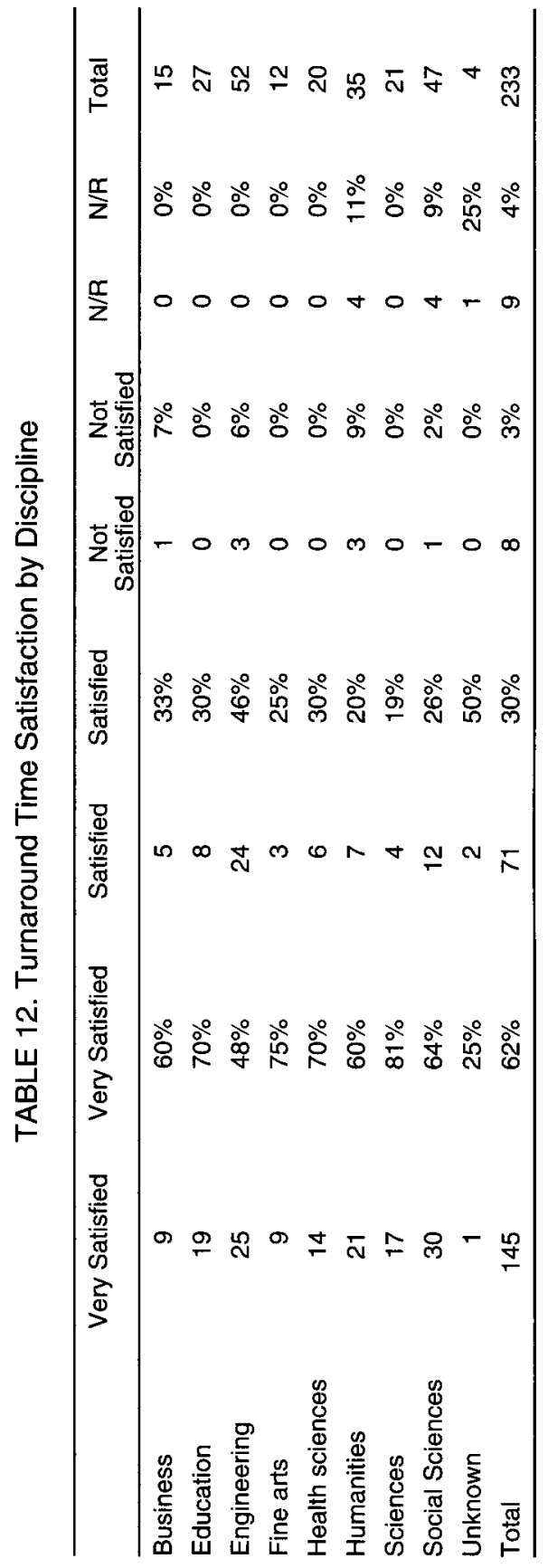


also interesting indicating that increasing "electrification" of information has changed the research landscape. Several comments indicated a reluctance to travel to the library when requested material was actually available in paper format. One comment deemed it a "headache," and another an "inconvenience" to come to the library to make copies from paper sources. The authors can remember when the photocopier was a major breakthrough in technology. The selected comments are included as Appendix B.

As with other articles that report upon user satisfaction, a significant limitation is its narrow scope. The authors recommend that researchers apply this methodology to the broader library community. This would create a better knowledge base concerning patron satisfaction with interlibrary loan, and would assist in future decisions regarding patron services.

\section{REFERENCES}

Berger, K. W. \& Hines, R. W. (1994). What does the user really want? The library user survey project at Duke University. Journal of Academic Librarianship, 20(5/6), 306.

Crowley, G. H. (1999). Unmediated document delivery: A project using FirstSearch and EBSCOdoc. Interlending \& Document Supply, 27(3), 122. DOI: 10.1108/ 02641619910285420.

Fong, Y. S. (1996). The value of interlibrary loan: An analysis of customer satisfaction survey comments. Journal of Library Administration, 23(1-2), 43.

Interlibrary loan and document delivery benchmarking study. (2001). Interlibrary Loan and Document Delivery Benchmarking Study, National Resource Sharing Working Group. (2001). Interlibrary Loan and Document Delivery Benchmarking Study, National Library of Australia, 2001.

Landes, S. (2001). Interlibrary loan survey: State University of New York College at Geneseo libraries. Journal of Interlibrary Loan, Document Delivery \& Information Supply, 11(4), 75. DOI: 10.1300/J110v11n04_06.

Levene, L., \& Pedersen, W. (1996). Patron satisfaction at any cost? A case study of interlibrary loan in two U.S. research libraries. Journal of Library Administration, 23(1-2), 55 .

Littlejohn, N. \& Wales, B. (1996). Assessment plan for interlibrary loan departments at academic libraries. Journal of Interlibrary Loan, Document Delivery \& Information Supply, 7(2), 3.

Perrault, A. H., \& Arseneau, M. (1995). User satisfaction and interlibrary loan service: A study at Louisiana State University. $R Q, 35(1), 90$.

Ruthven, T., \& Magnay, S. (2002). Top performing interlending operations: Results of the Australian benchmarking study. Interlending \& Document Supply, 30(2), 73. DOI: $10.1108 / 02641610210430532-79$.

Shoge, R. (2001). ClioWeb, ClioRequest, and Clio database: Enhancing patron and staff satisfaction. Journal of Interlibrary Loan, Document Delivery \& Information Supply, 12(2), 71. DOI: 10.1300/J110v12n02_05-87. 
Stabler, K. (2002). Benchmarking inter library loan and document delivery services: Lessons learned at New Mexico State University. Journal of Interlibrary Loan, Document Delivery \& Information Supply, 12(3), 57. DOI: 10.1300/J110v12n03_05.

Tonn, A. (2003). Interlibrary loan internet accessible database (ILLiad): A patron focused satisfactory interlibrary loan service study. Journal of Interlibrary Loan, Document Delivery \& Information Supply, 14(2), 49. DOI: 10.1300/J110v14n02_ 06-63.

Weaver-Meyers, P. L., \& Stolt, W. A. (1996). Delivery speed, timeliness and satisfaction: Patrons' perceptions about interlibrary loan service. Journal of Library Administration, 23(1/2), 23.

Wessling, J., \& Delaney, T. (2003). RAPID: A new level of collaboration for interlibrary loan. Colorado Libraries, 29(1), 22-24.

Yang, Z. (2004). Customer satisfaction with interlibrary loan service- deliverEdocs: A case study. Journal of Interlibrary Loan, Document Delivery \& Information Supply, 14(4), 79. DOI: 10.1300/J110v14n04_07-94.

Received: 05/12/07

Revised: 06/15/07

Accepted: 07/17/07 